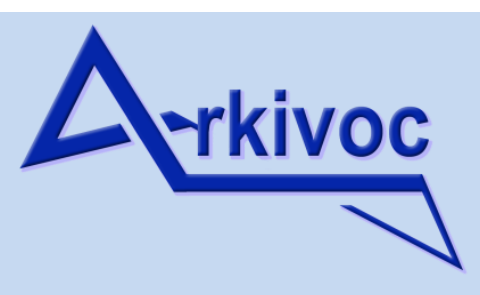

Archive for

Organic Chemistry
The Free Internet Journal

for Organic Chemistry
Paper

Arkivoc 2017, part v, 341-355

\title{
New "turn-off" fluorescence sensors to detect vapors of nitro-explosives on the basis of 4,6-bis[5-(heteroaryl)thiophen-2-yl] substituted 5-(4-tert- butylphenyl)pyrimidines
}

\author{
Egor V. Verbitskiy, ${ }^{* a, b}$ Anna A. Baranova, ${ }^{\text {b }}$ Yuliya A. Yakovleva, ${ }^{b}$ \\ Roman D. Chuvashov, ${ }^{b}$ Konstantin O. Khokhlov, ${ }^{b}$ Ekaterina M. Dinastiya, ${ }^{a}$ \\ Gennady L. Rusinov, ${ }^{a, b}$ Oleg N. Chupakhin, ${ }^{a, b}$ and Valery N. Charushin ${ }^{a, b}$ \\ a Postovsky Institute of Organic Synthesis, Ural Branch of the Russian Academy of Sciences, \\ S. Kovalevskoy St. 22, Ekaterinburg 620 990, Russia \\ ${ }^{b}$ Ural Federal University, Mira St. 19, Ekaterinburg 620 002, Russia \\ Email: Verbitsky@ios.uran.ru
}

Received 10-04-2017

Accepted 10-17-2017

Published on line 11-30-2017

\section{Abstract}

New $D-\pi-A-\pi-D$ type dyes based on compounds of the pyrimidine family, bearing thiophene linkers, have been designed, synthesized and characterized. The fluorescence behavior of these fluorophores have been evaluated for fifteen nitro compounds. The detection limits for these fluorophores in relation to nitro explosives in acetonitrile solution proved to be in the range from $10^{-1}$ to $10^{-6} \mathrm{~mol} / \mathrm{L}$. The sensor prototypes for handheld sniffer «Nitroscan» (Plant «Promautomatika», Ekaterinburg, Russia), based on these fluorophores, have been fabricated and used, as illustrated by reversible and sensitive fast detection of nitrobenzene in vapor phase concentrations up to $0.06 \mathrm{ppm}$.

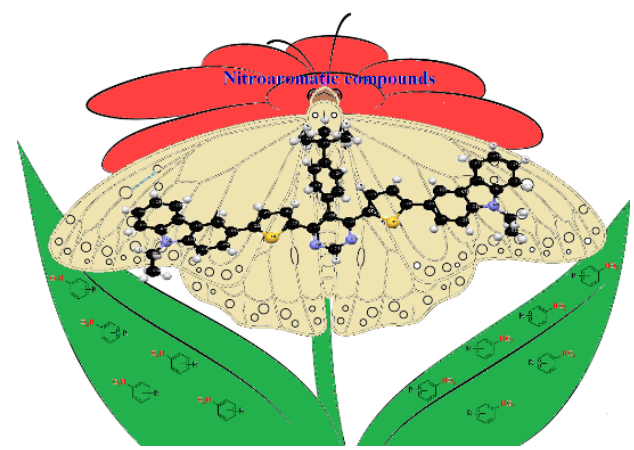

Keywords: Pyrimidines, carbazoles, triphenylamines;,pyrene, nitroaromatic explosives, fluorescence quenching 


\section{Introduction}

Discovery of new materials and development of effective devices for detection of explosives has attracted world-wide attention, because it is critical for homeland security, civilian safety, and environmental protection. ${ }^{1-}$ ${ }^{5}$ Instrumental methods, which are generally used to detect nitro explosives, include gas chromatography coupled with mass spectrometry, ${ }^{6-8}$ nuclear quadrupole resonance, ${ }^{9}$ energy dispersive X-ray diffraction, ${ }^{10}$ and ion mobility spectrometry (IMS), ${ }^{11,12}$ but all these methods are rather expensive, and can hardly be made portable. In addition, many of these techniques require special equipment and/or need in pre-concentrating procedures. $^{13,14}$

On the other hand, there are a number of commercially available, portable (hand-held and stand-off) chemical detection sniffers (sensors working as an artificial dog's nose), exploiting advantage of materials, which are capable of detection of explosives through smell of these compounds. ${ }^{15}$ "Fido X2» (weighs $680 \mathrm{~g}$ ), "Fido X3" (weighs $1.36 \mathrm{~kg}$ ), and «Fido NXT» (weighs $1.36 \mathrm{~kg}$ ) from FLIR Systems Inc. (Wilsonville, Oregon, USA) ${ }^{16}$ are the most famous lightweight, hand portable fluorescence polymer sensors for rapid detection of explosives, operating in many United States airports. "Nitroscan» (weighs $2.00 \mathrm{~kg}$ ) is the Russian portable detector of nitroexplosives, produced by «Promautomatika» Plant in collaboration with «UralProektAvtomatika» and "Security Intermolecular System» (Ekaterinburg, Russia). ${ }^{17}$ In this device, fluorescence-based sensors have been used, due to their high sensitivity, selectivity, simplicity, and a low cost in fabrication.

Organic materials, bearing electron-rich fragments, such as triphenylamine, carbazole or pyrene, conjugated with either monomeric or polymeric molecules, have received a considerable attention due to their promising properties as fluorescent chemosensors. ${ }^{18-23} \mathrm{It}$ is known, that $\pi$-deficient azaaromatic compounds, such as pyridines ${ }^{24-26}$ or pyrimidines, ${ }^{27-32}$ can be used as electron-withdrawing units in the so-called "push-pull" luminophores. Such structures have been used as promising sensing materials for detection of a variety of nitroaromatics through fluorescence quenching. ${ }^{33-40}$

As a part of our research studies on pyrimidine-based $\pi$-conjugated systems, we envisaged that mixed $\pi$ conjugated 4,6-bis[5-(heteroaryl)-thiophen-2-yl]-5-(4-tert-butylphenyl) pyrimidines, consisting of the electrondonating part, presented by triphenylamine, carbazole or pyrene fragments, and the electron-withdrawing pyrimidine unit, would be a new class of push-pull fluorophores with improved sensitivity towards nitroaromatic compounds. Indeed, we have been motivated to synthesize $D-\pi-A-\pi-D$ conjugates $7 a-c$, in which electrondonating groups are attached to 4- and 6-positions of the pyrimidine ring via the thiophene spacer and 4-tertbutylphenyl substituent is incorporated at C-5 of pyrimidines. Although some 4,6-(hetero)aryl substituted pyrimidines have been synthesized, ${ }^{28,41}$ no reports on 4,6-bis(carbazol-3-yl) pyrimidines have so far been published.

We describe herein the synthesis and the photophysical properties of 7a-c on the basis of UV-vis and fluorescence spectral measurements. The sensitivity and selectivity to the presence of some nitroaromatic explosives in very small quantities, both in vapor and in solution phases, thus causing a significant quenching of the emission is also evaluated.

\section{Results and Discussion}

The starting material in the performed syntheses was 5-(4-tert-butylphenyl)-4,6-di(thiophen-2-yl)pyrimidine (4). To prepare compound $\mathbf{4}$ from readily available 5 -bromo-4-(thiophen-2-yl)pyrimidine (1), a previously developed synthetic protocol involving nucleophilic aromatic substitution of hydrogen (for a better understanding of the 
$\mathrm{S}_{\mathrm{N}}{ }^{\mathrm{H}}$-reactions, see the recently published review, ${ }^{42}$ and references, cited therein) and Suzuki cross-coupling has been used (Scheme 1). ${ }^{43}$ Further bromination of pyrimidine 4 with 5 equiv. of $N$-bromosuccinimide (NBS) in DMF at room temperature gave 4,6-bis(5-bromothiophen-2-yl)-5-(4-tert-butylphenyl)pyrimidine (5) in 92\% yield. Compound 5 can be coupled easily with the corresponding pinacol esters of 4-(diphenylamino)phenylboronic (6a), 9-ethyl-9H-carbazole-3-boronic (6b) acids or pyrene-1-boronic acid (6c) under microwave irradiation in 1,4dioxane/ $\mathrm{H}_{2} \mathrm{O}$ in the presence of $\mathrm{K}_{2} \mathrm{CO}_{3}$ and $\mathrm{Pd}\left(\mathrm{PPh}_{3}\right)_{4}$, as catalyst. All reactions studied proved to afford the corresponding $D-\pi-A-\pi-D$ dyes 7a-c [where A - acceptor, the pyrimidine unit, D - a donating part, presented by triphenylamine, carbazole or pyrene fragments, and $\pi$-system is presented by a thienyl group] in $59-82 \%$ yields within the reaction time, not exceeding $30 \mathrm{~min}$ (Scheme 1).

The structural evidence for compounds $7 \mathrm{a}$-c has been provided by their spectral data, including ${ }^{1} \mathrm{H}$ and ${ }^{13} \mathrm{C}$ NMR (see Supporting Information), and the data of high-resolution mass spectrometry. Furthermore, the structure of 3,3'-\{5,5'-[5-(4-tert-butylphenyl)pyrimidine-4,6-diyl]bis(thiophene-5,2-diyl)\}bis(9-ethyl-9Hcarbazole) (7b) has been established unequivocally by X-ray crystallography analysis (Figure 1).
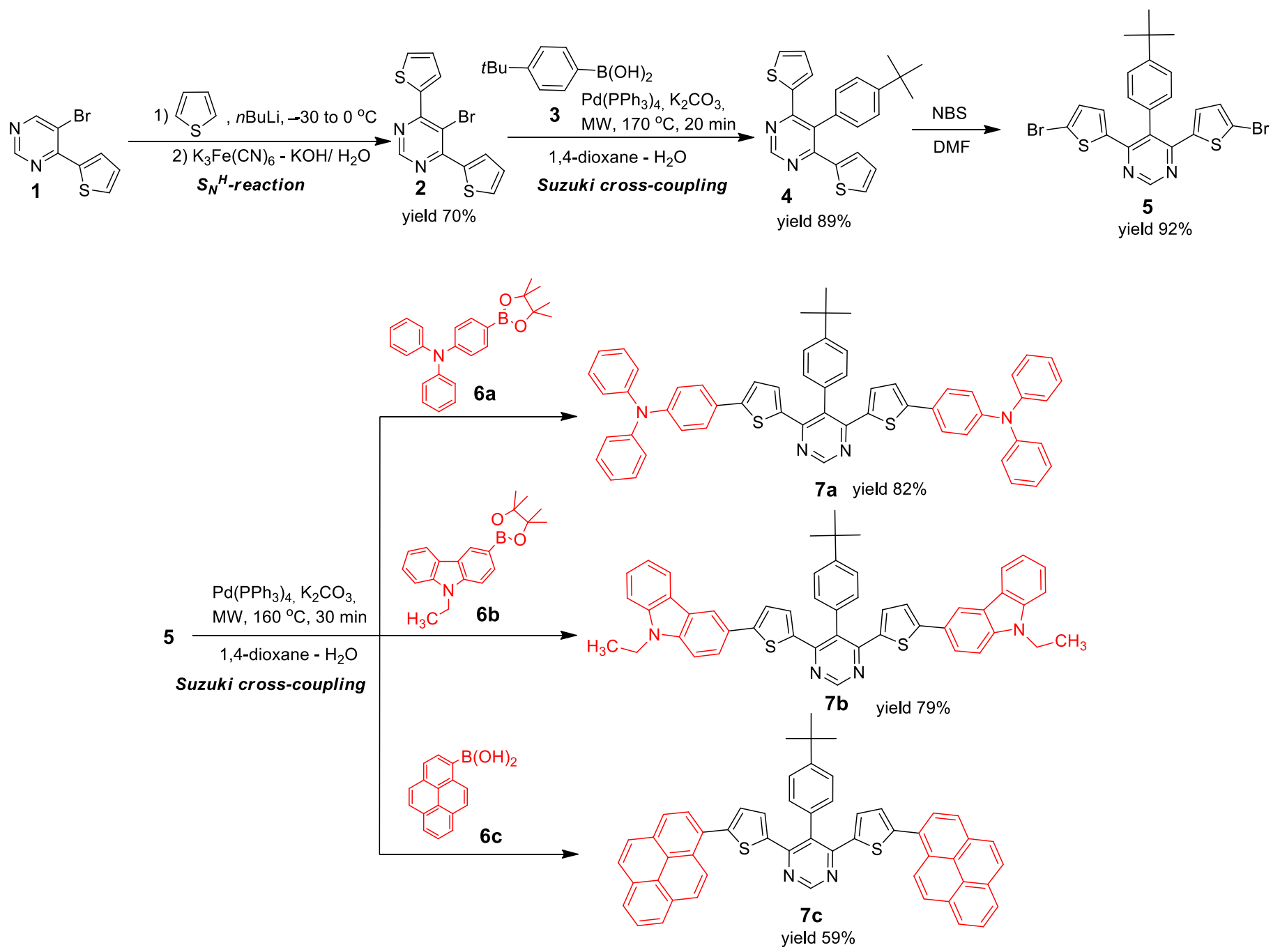

Scheme 1. Synthetic route to 4,6-bis[5-(heteroaryl)-thiophen-2-yl]-5-(4-tert-butylphenyl)pyrimidines (7a-c). 


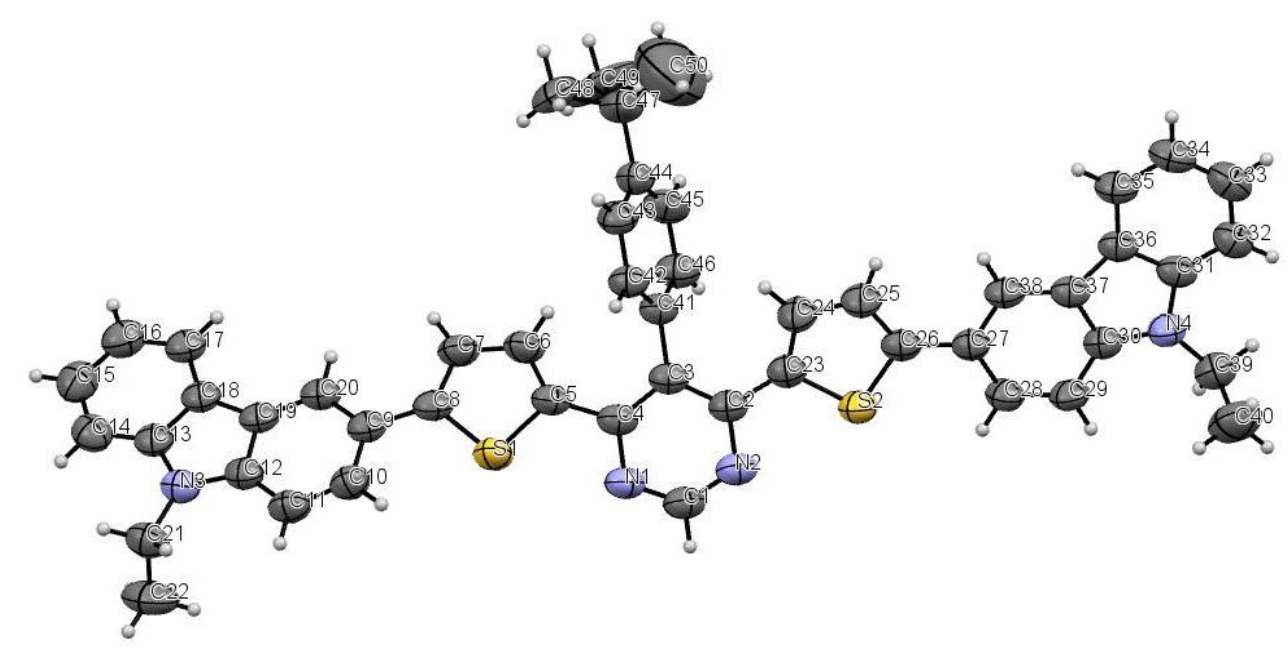

Figure 1. An ORTEP diagram of compound 7b, showing 50\% probability thermal ellipsoids.

\section{Optical properties and fluorescence quenching studies in acetonitrile solution}

A characteristic trait of this class of compounds is that their absorption and emission wavelengths can be adjusted by careful tuning of their molecular structures. To evaluate the effect of triphenylamine, carbazole and pyrene moieties on photophysical properties, the fluorescence excitation and emission spectra of 7a-c have been recorded. The spectra are shown in Figure 2 and the main optical properties are given in Table 1.

(a)

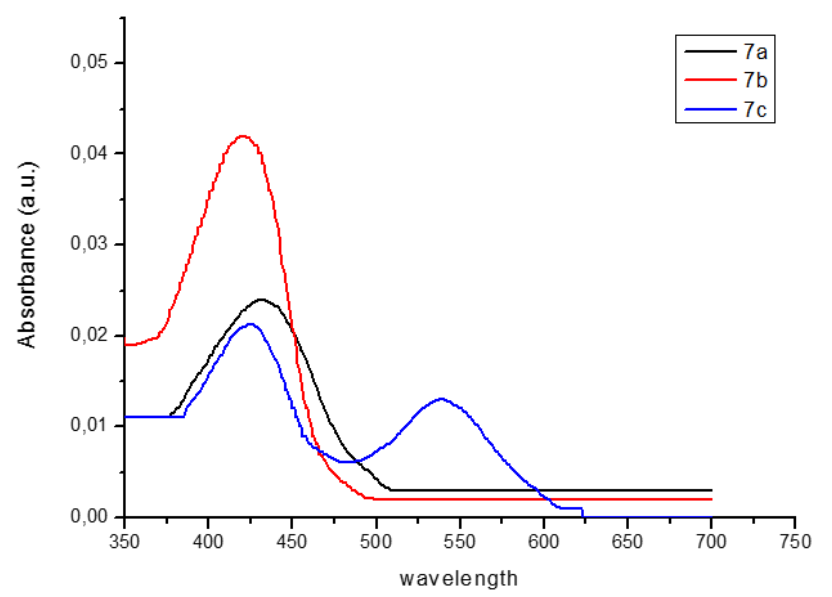

(b)

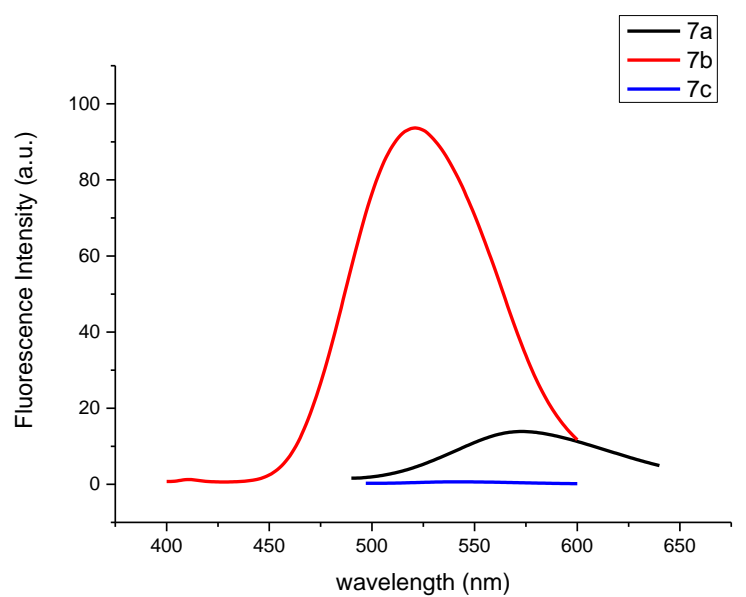

Figure. 2. Absorption and emission spectra of fluorophores 7a-c. (a) Absorption spectra of 7a-c in $\mathrm{CH}_{3} \mathrm{CN}$. (b) Emission spectra of $7 \mathrm{a}-\mathrm{c}$ in $\mathrm{CH}_{3} \mathrm{CN}$.

Table 1. Photophysical data for fluorophores 7a-c taken in acetonitrile

\begin{tabular}{|c|c|c|c|c|c|}
\hline \multirow[b]{2}{*}{ Fluorophores } & \multirow{2}{*}{$\begin{array}{l}\text { Absorption } \\
\lambda_{\max }(\mathrm{nm}) / \varepsilon \\
\left(10^{3} / \mathrm{M}^{-1}\right. \\
\left.\mathrm{cm}^{-1}\right)\end{array}$} & \multicolumn{2}{|c|}{ Fluorescence } & \multirow[b]{2}{*}{$\begin{array}{l}\text { Quantum } \\
\text { yield }(\Phi)\end{array}$} & \multirow[b]{2}{*}{$\begin{array}{l}\text { Stokes shift } \\
\Delta v_{\text {st }} / \mathrm{cm}^{-1}\end{array}$} \\
\hline & & $\begin{array}{l}\text { Excitation } \\
\lambda_{\max }(\mathrm{nm})\end{array}$ & $\begin{array}{l}\text { Emission } \\
\lambda_{\max }(\mathrm{nm})\end{array}$ & & \\
\hline $7 a$ & $433 / 23.00$ & 433 & 572 & 0.04 & 5612 \\
\hline $7 b$ & $412 / 43.00$ & 412 & 519 & 0.07 & 5004 \\
\hline 7c & $\begin{array}{l}430 / 18.00 \\
528 / 12.00\end{array}$ & 528 & 541 & 0.003 & 455 \\
\hline
\end{tabular}


Fluorophores 7a-c have been established to show broad absorption maxima at the region of 412-528 nm $\left(\varepsilon=12000-43000 \mathrm{M}^{-1} \cdot \mathrm{cm}^{-1}\right.$ ), which can be attributed to intramolecular charge-transfer excitation from the donating moiety to the pyrimidine ring (Table 1, Fig. 2a). The solutions of all compounds 7a-c have moderate green-orange luminescence with emission maxima at 519-572 nm (Table 1, Fig. 2b); thus, relative quantum yields varies from $0.3 \%$ to $7.0 \%$.

To evaluate an ability of the $D-\pi-A-\pi-D$ type dyes $7 \mathbf{a}, \mathbf{b}$ on the basis of the pyrimidine scaffold to detect nitro-explosives, the fluorescence measurements of $\mathbf{7 a , b}$ have been carried out in acetonitrile solutions, containing measured quantities of nitroaromatic compounds, as quenchers of the fluorescence (Figure 3). It should be noted that the fluorescence measurements of compound $7 \mathrm{c}$ in acetonitrile solutions at the presence of nitro-explosives was not carried out by reason of poor relative quantum yield $<1 \%$. However, compound $7 \mathrm{c}$ was possessed of the satisfactory fluorescence in solid state (see Figure S1 in Supplementary Material) and it was also used for detection of nitroaromatic vapors.

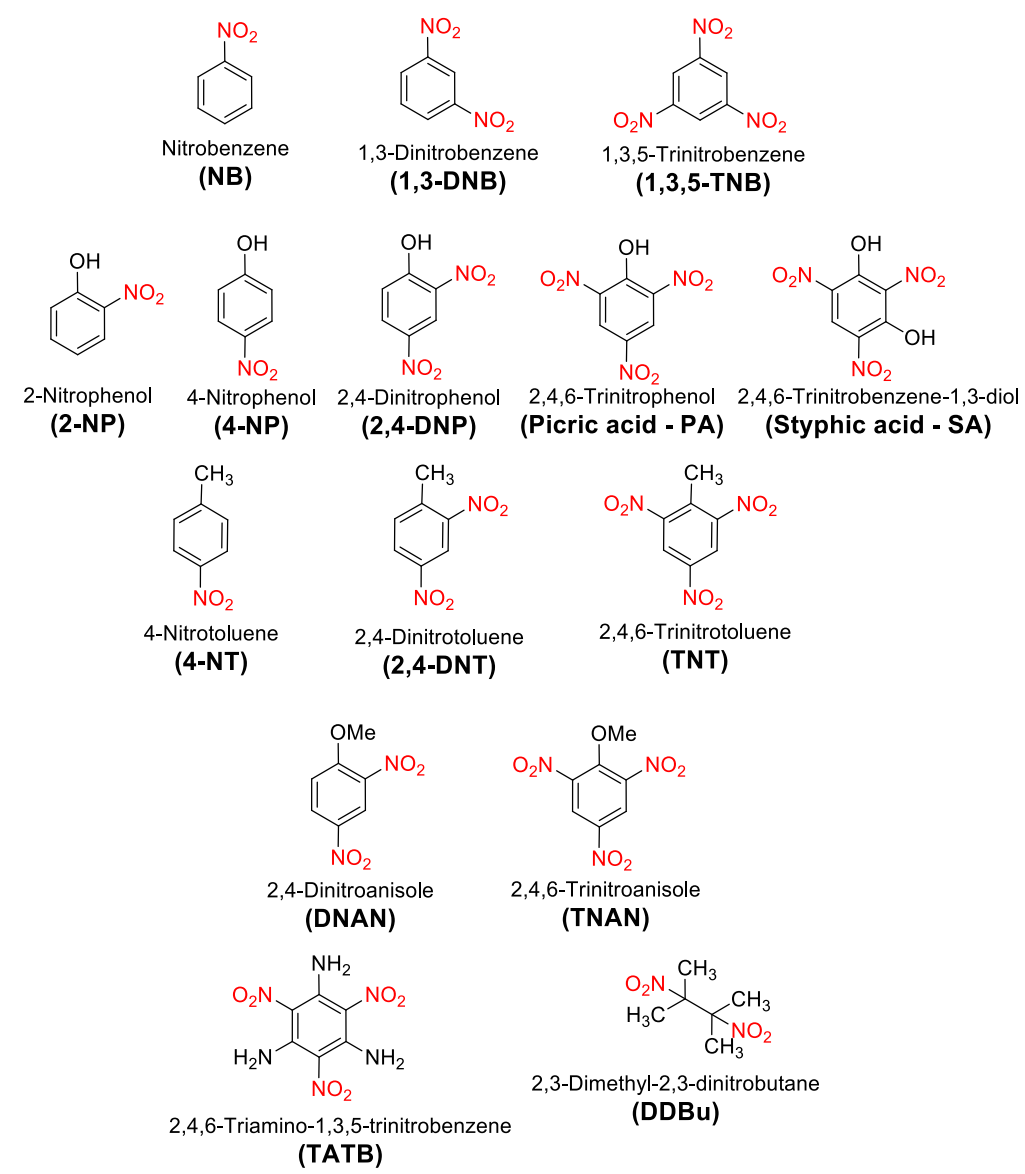

Figure 3. Structures of used quenchers.

Figures S2 and S3 (see Supplementary Material) show the fluorescence emission spectra of $\mathbf{7 a , b}$ in the presence of various concentrations of the analytes with 412 or $433 \mathrm{~nm}$, as the excitation wavelength. All nitroaromatics appear to act as fluorescence quenchers for compounds 7a-c (Table 2). Visual changes of color for solutions of fluorophores 7a,b with additives of different quenchers are shown in Figures S4 and S5 (see Supporting Information). Fluorophore $\mathbf{7 b}$ have higher values of the quenching constants $K_{\text {sv }}$ and detection limits (DL) (see Table 2) than fluorophore 7a, which are in a good agreement with values of quantum yields (see Table 1). 
Quenching efficiency was calculated by using the formula $\left(I_{0}-I\right) / I_{0} \times 100 \%$, where $I_{0}$ and $I$ are the fluorescence intensities of fluorophores $\mathbf{7 a}$ and $\mathbf{7 b}$ before and after exposure to a particular analyte, respectively. Figure 4 shows quenching efficiency of various nitroaromatics and DDBu towards fluorophores 7a,b.

It can be seen that this fluorophores $7 \mathbf{a}, \mathbf{b}$ exhibit fast and sensitive response to nitrobenzene, and nearly $64-85 \%$ of the original emission values are quenched by these fluorophores, when their concentrations reach $5 \times 10^{-7} \mathrm{~mol} / \mathrm{L}$. In other words, the most effective quencher proved to be nitrobenzene, while other NACs are less effective ones (Figs. 4, S4 and S5, entry 4). In our opinion, the most reasonable explanation of this fact is a steric hindrances increase with an addition of substituents in benzene ring.

Table 2. Quenching constants $\left(K_{S V}\right)$ and detection limits (DL) of NB, 1,3-DNB, 1,3,5-TNB, 2-NP, 4-NP, 2,4-DNP, PA, SA, 4-NT, 2,4-DNT, TNT, DNAN, TNAN, TATB and DDBu towards fluorophores $7 a, b$ in $\mathrm{CH}_{3} \mathrm{CN}$.

\begin{tabular}{lll}
\hline \multirow{2}{*}{ Nitro-compound } & \multicolumn{2}{c}{$K s, \mathrm{M}^{-1} / \mathrm{DL}, \mathrm{mol} \times \mathrm{L}^{-1}$} \\
\cline { 2 - 3 } & Fluorophore $7 \mathrm{a}$ & Fluorophore $7 \mathrm{~b}$ \\
\hline NB & $1443 / 7.98 \times 10^{-3}$ & $3509 / 6.64 \times 10^{-6}$ \\
$1,3-\mathrm{N} B$ & $293 / 2.92 \times 10^{-2}$ & $1138 / 9.53 \times 10^{-6}$ \\
$1,3,5-$-TNB & $274 / 4.20 \times 10^{-2}$ & $520 / 2.32 \times 10^{-5}$ \\
2 -NP & $75 / 1.54 \times 10^{-1}$ & $428 / 2.39 \times 10^{-5}$ \\
$4-N P$ & $205 / 5.62 \times 10^{-2}$ & $363 / 3.16 \times 10^{-5}$ \\
$2,4-D N P$ & $159 / 7.22 \times 10^{-2}$ & $156 / 5.30 \times 10^{-5}$ \\
PA & $160 / 7.30 \times 10^{-2}$ & $195 / 8.68 \times 10^{-5}$ \\
SA & $268 / 4.29 \times 10^{-2}$ & $802 / 1.63 \times 10^{-5}$ \\
$4-N T$ & $350 / 3.29 \times 10^{-2}$ & $124 / 6.20 \times 10^{-5}$ \\
$2,4-D N T$ & $314 / 3.67 \times 10^{-2}$ & $83 / 8.99 \times 10^{-5}$ \\
TNT & $67 / 1.71 \times 10^{-1}$ & $245 / 2.68 \times 10^{-5}$ \\
DNAN & $114 / 1.01 \times 10^{-1}$ & $224 / 4.51 \times 10^{-5}$ \\
TNAN & $113 / 1.00 \times 10^{-1}$ & $111 / 7.35 \times 10^{-5}$ \\
TATB & $605 / 1.90 \times 10^{-2}$ & $135 / 4.08 \times 10^{-5}$ \\
DDBu & $466 / 2.47 \times 10^{-2}$ & $92 / 8.46 \times 10^{-5}$ \\
\hline
\end{tabular}

(a)

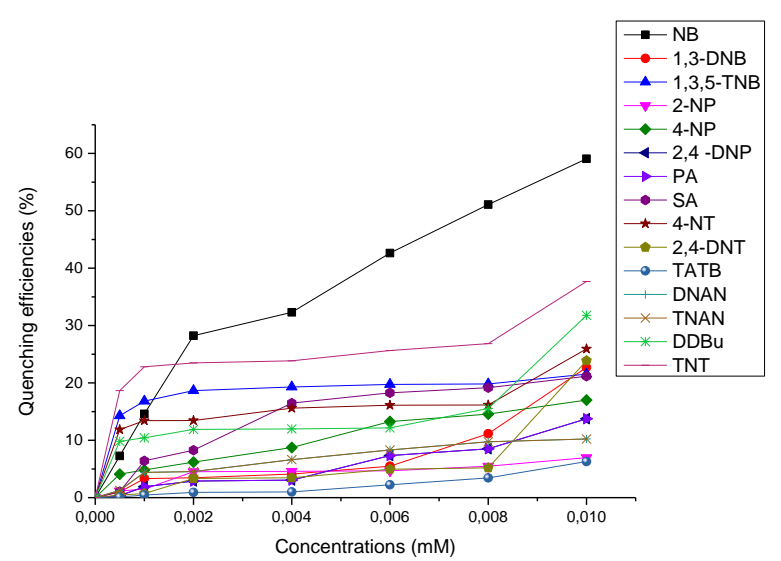

(b)

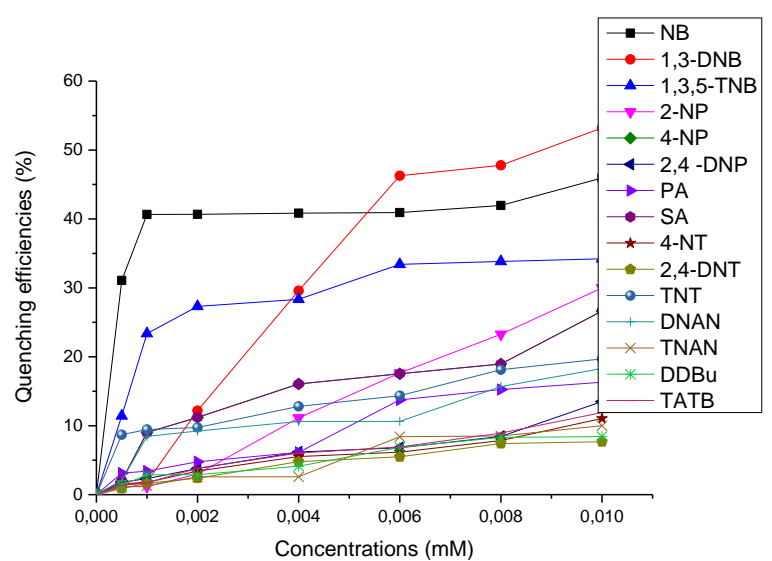

Figure 4. The plot of quenching efficiencies of NB, 1,3-DNB, 1,3,5-TNB, 2-NP, 4-NP, 2,4-DNP, PA, SA, 4-NT, 2,4DNT, TNT, DNAN, TNAN, TATB relative to fluorophores $7 \mathbf{a}(a)$ and $7 \mathbf{b}(b)$ at $\mathrm{mM}$ level. 
The linear relationship for the Stern-Volmer plot (in the range of concentrations from 0 to $2 \times 10^{-6} \mathrm{M}$ ) (Figures S6 and S7 in Supporting Information) and similarity of structures with linear and V-shaped push-pull pyrimidines, ${ }^{35,40}$ bearing triphenylamine and carbazole as electron-donating fragment, suggests a high role of static type interactions for the quenching process.

\section{Application of sensors in detecting of the nitroaromatic vapors}

Nitrobenzene (NB) is mainly consumed in production of aniline, which is a precursor to rubber chemicals, pesticides, dyes (azo dyes), explosives, and pharmaceuticals. As a chemical material, it is also used in shoes and floor polishes, leather dressings, paints, organic solvents, etc. Also it is known, that NB is a highly toxic and carcinogenic agent (value of maximal allowable concentration $3 \mu \mathrm{g} / \mathrm{m}^{3}$ ), which is readily absorbed through the skin. Therefore, both environment and human health issues, caused by application of NB, have attracted a great attention of scientific community. ${ }^{44}$ As mentioned, 2,4,6-trinitrotoluene (TNT) plays an important role not only in the military field, as a highly explosive material, but it is a highly toxic environment pollutant. ${ }^{45}$ Many improvised explosive devices are fabricated by using impure TNT, in which the major impurity is 2,4-DNT used as the starting material for TNT synthesis. Notably, that sensing of nitroaromatic explosives is rarely applied to solutions or extracts.

We have decided to use NB, 2,4-DNT and TNT as model substances to evaluate their detection in vapor phase. To realize this, we have implemented the real-time solid-gas monitoring of nitrobenzene vapor by using a sensor with each of fluorophores 7a-c on the basis of non-woven spunlace fabric placed in the portable sniffer «Nitroscan» (all details of sensor fabrication are reported in the Experimental Part).

At the first step, nitrobenzene $2.5 \mu \mathrm{L}(3 \mathrm{mg})$ in $\mathrm{CH}_{3} \mathrm{CN} 100 \mu \mathrm{L}$ has been sprayed by a syringe in a hermetic glove-box $(0.8 \mathrm{~m} \times 0.6 \mathrm{~m} \times 0.4 \mathrm{~m})$ and kept in this box during $12 \mathrm{~h}$ at room temperature to achieve a maximal allowable concentration $(0.6 \mathrm{ppm})$ of nitrobenzene. It has been shown that all sensors $7 \mathrm{a}-\mathrm{c}$ are capable of a fast reversible self-recovery after interruption of exposure to nitroaromatic explosive. Reversibility of the sensing process for sensors on the basis of fluorophores 7a-c 0.6 ppm NB vapor was examined by using the following procedure: The device «Nitroscan», bearing a sensor, was inserted into a glove box with saturated NB vapor for $50 \mathrm{~s}$, and then the fluorescence intensity was recorded. After that, the device was removed from the box for 50 $\mathrm{s}$, and the ambient room air was pumped automatically through the sensor in device. The recovered fluorescence efficiency of the sensor was measured. The sensing and pumped process was repeated 5 times, and the results obtained are shown in Figure 5.

Evaluation of the process at various lower concentrations of NB shows that all sensors 7a-c have a high sensitivity up to 0.6 NB (Figure 5). Furthermore, fluorophore $7 \mathbf{b}$ can detect nitrobenzene at 6 ppb concentration on air that is in a good agreement with a quenching evaluation in solution. 
(a)

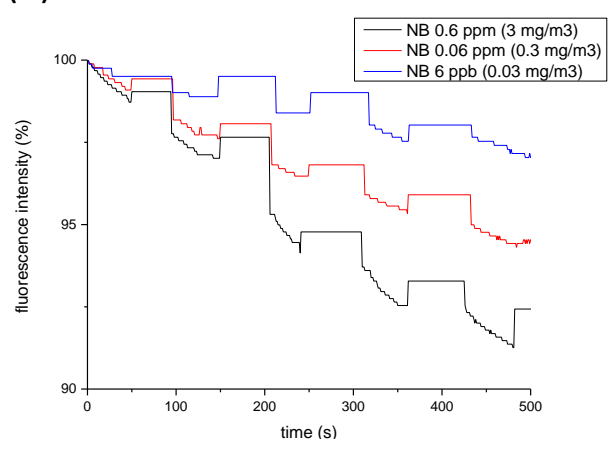

(b)

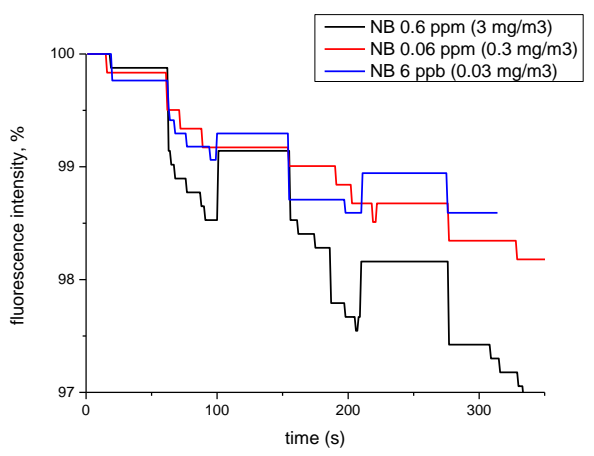

(c)

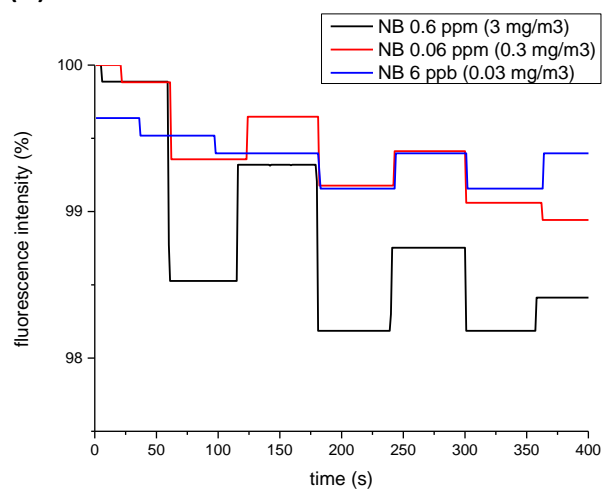

Figure 5. Fluorescent recovery cycles for the sensors on the basis of compounds 7a $(a), 7 \mathbf{b}(b)$ and $7 \mathbf{c}(c)$ in device «Nitroscan» with exposure to NB vapor in a range of concentration from $0.6 \mathrm{ppm}$ to $6 \mathrm{ppb}$.

Similar protocol was used for detection of 2,4-DNT and TNT vapors at low concentrations by sensors 7a-c. The results are summarized in Figures 6 and 7. It was found, that fluorophores can satisfactory detect 2,4-DNT and TNT vapors at concentrations higher than $0.13 \mathrm{ppm}$ and $0.05 \mathrm{ppm}$, respectively. As shown in Figures 5-7, the quenching efficiency reaches remarkable values after exposing the device with any type of sensor in the box for $100 \mathrm{~s}$ but the recovered fluorescence intensity is decreasing with each next cycle.

(a)

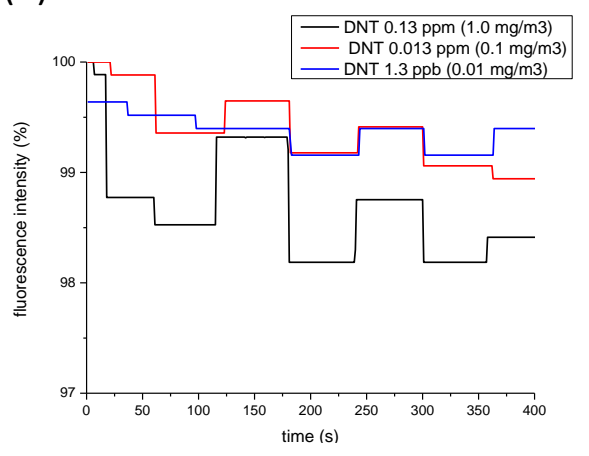

(b)

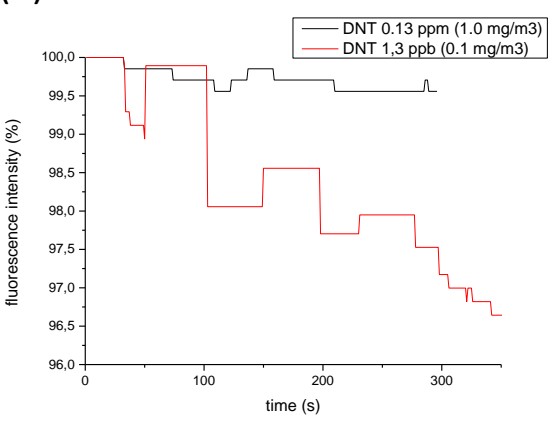

(c)

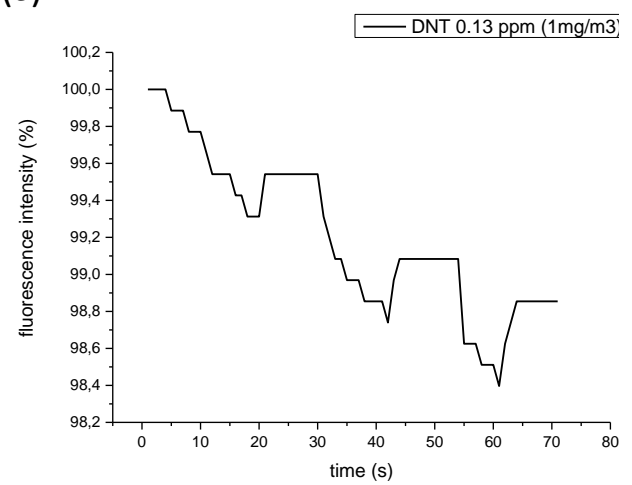

Figure 6. Fluorescent recovery cycles for the sensors on the basis of compounds $7 \mathbf{a}(a), 7 \mathbf{b}(b)$ and $7 \mathbf{c}(c)$ in device «Nitroscan» with exposure to 2,4-DNT vapor in a range of concentration from $0.13 \mathrm{ppm}$ to $1.3 \mathrm{ppb}$.

(a)

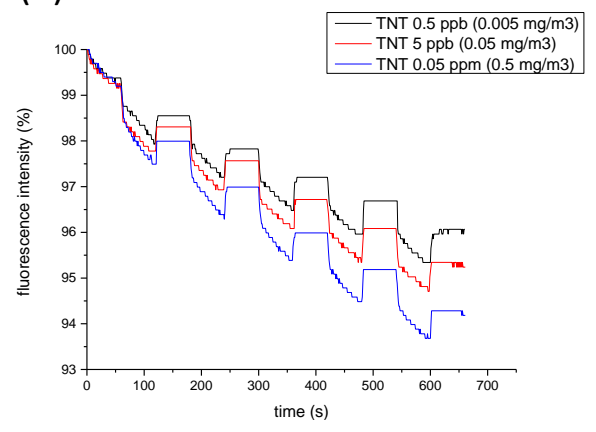

(b)

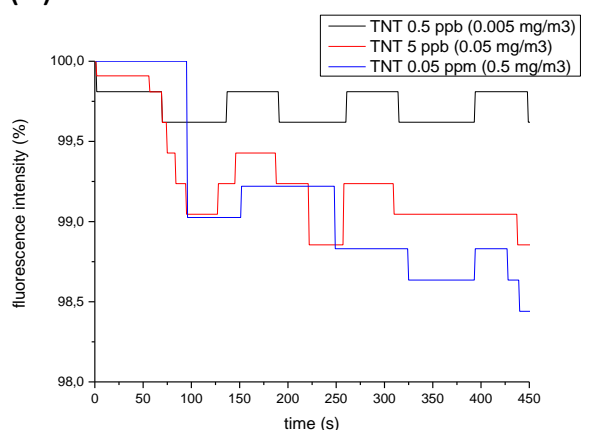

(c)

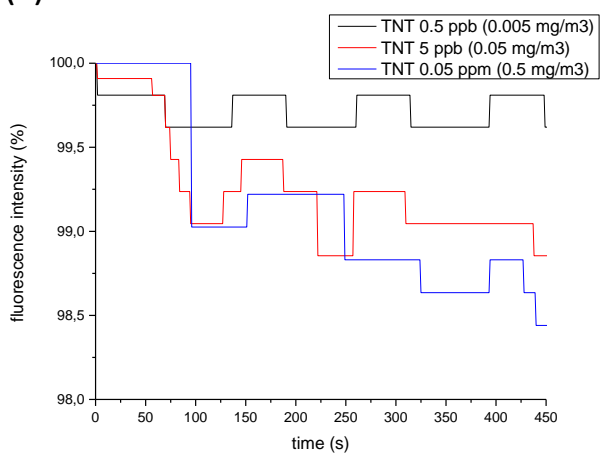

Figure 7. Fluorescent recovery cycles for the sensors on the basis of compounds $7 \mathbf{a}(a), 7 \mathbf{b}(b)$ and $7 \mathbf{c}(c)$ in device «Nitroscan» with exposure to TNT vapor in a range of concentration from $0.05 \mathrm{ppm}$ to $0.5 \mathrm{ppb}$. 
To investigation the selectivity and sensitivity for the sensors 7a-c we compared the quenching efficiencies at the presence of maximum allowable concentrations of NB, 2,4-DNT and TNT $(0.6,0.13$ and $0.05 \mathrm{ppm}$, respectively) ${ }^{46}$ and saturated vapors of some interferents, such as ethanol, ethylene glycol, acetone, acetic acid, toluene, phenol, and 1,2-dichlorobenzene (see Figure 8). As expected, sensors 7a and $7 \mathbf{b}$ show a good selectivity to NB in comparison with other explosives and interferents, since their quenching sensitivities are weaker in these vapors that in NB.

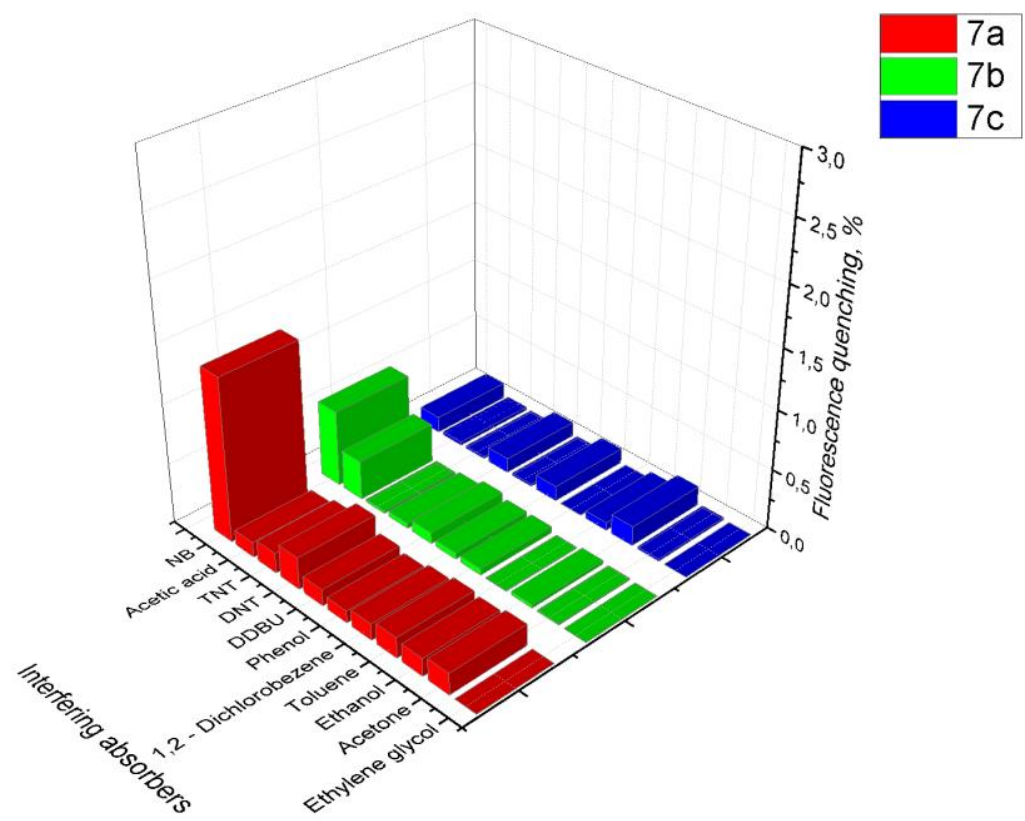

Figure 8. Sensor's 7a-c fluorescence quenching (\%) in first cycle towards various nitro-explosives and volatile interferents at room temperature.

\section{Conclusions}

Three dyes of the $D-\pi-A-\pi-D$ type on the basis of pyrimidines, bearing thiophene $\pi$-linkers and various electrondonative fragments, have been studied, as sensing fluorophores. All dyes demonstrate a high sensitivity towards nitroaromatic explosives.

Selective fluorescence quenching response, including a sharp color change under UV lamp (especially for $\mathrm{NB}$ ), makes these fluorophores into solution to be promising fluorescence sensor materials for nitroaromatic explosives with the detecting limit up to $10^{-6} \mathrm{~mol} / \mathrm{L}$, as estimated in experiments with NB.

Furthermore, the compounds obtained can be regarded as good sensing materials for the handheld sniffer «Nitroscan» (Plant «Promautomatika», Ekaterinburg, Russia), since they exhibit a good potential, and pretend to be fast-response and highly sensitive sensors for detection of NB in vapors.

The present study can be regarded as a significant step to develop a new series of push-pull type sensing fluorophores with the pyrimidine core. 


\section{Experimental Section}

General. All reagents and solvents were obtained from commercial sources and dried by using standard procedures before use. Nitroaromatic explosives, including 1,3-dinitrobenzene (1,3-DNB), 1,3,5-trinitrobenzene (1,3,5-TNB), 2-nitrophenol (2-NP), 4-nitrophenol (4-NP), 2,4-dinitrophenol (2,4-DNP), picric acid (PA), styphnic acid (SA), 4-nitrotoluene (4-NT), 2,4-dinitrotoluene (DNT), 2,4,6-trinitrotoluene (TNT), 2,4-diniroanisole (DNAN), 2,4,6-triniroanisole (TNAN) and 2,4,6-triamino-1,3,5-trinitrobenzene (TATB) were of analytical grade and used directly without further purification. (Caution: All nitro-containing compounds used in the present study are high explosives and should be handled only in small analytical quantities.)

The solvents (1,4-dioxane and $\mathrm{H}_{2} \mathrm{O}$ ) for the Suzuki cross-coupling reaction were deoxygenated by bubbling argon for $1 \mathrm{~h}$.

${ }^{1} \mathrm{H}$ and ${ }^{13} \mathrm{C}$ NMR spectra were recorded on an AVANCE-500 instruments using $\mathrm{Me}_{4} \mathrm{Si}$ as an internal standard. Elemental analysis was carried on a Eurovector EA 3000 automated analyzer. High-resolution mass spectrometry was performed using a Bruker maXis Impact HD spectrometer. Melting points were determined on Boetius combined heating stages and were not corrected.

Flash-column chromatography was carried out using Alfa Aesar silica gel 0.040-0.063 mm (230-400 mesh), eluting with ethyl acetate-hexane. The progress of reactions and the purity of compounds were checked by TLC on Sorbfil plates (Russia), in which the spots were visualized with UV light ( $\lambda 254$ or $365 \mathrm{~nm}$ ).

UV-vis spectra were recorded for a $1 \times 10^{-5} \mathrm{M}$ acetonitrile solution with Shimadzu UV-2401PC spectrophotometer. Fluorescence spectra measurements were performed on a Hitachi F-7000 fluorescence spectrophotometer at room temperature. Quantum yields $(\Phi)$ were estimated with $1 \mathrm{~N}_{2} \mathrm{SO}_{4}$ solution of quinine bisulfate $(\phi=0.55)$ as a reference. ${ }^{47}$

The fluorescence quenching studies were carried out in acetonitrile. For each analyte, the typical test procedure was as follows: $2.5 \mathrm{~mL}$ of acetonitrile solution of one of the fluorophores $\left(1.0 \times 10^{-5} \mathrm{~mol} / \mathrm{L}\right)$ was drawn and placed in a quartz cell of the standard size. Without analyte the fluorescence spectrum of pure fluorophore was first recorded. Subsequently, different amounts of analyte were added respectively in the cell. Each time after full mixing the analyte with fluophore, the fluorescence spectrum was registered. The plots of $I_{0} / I$ values of the quenching systems as functions of quencher concentrations $([Q])$ were well described by the Stern-Volmer equation, $I_{0} / I=1+K_{\mathrm{sv}}[Q]$, where $I_{0}$ and $I$ are fluorescence intensities without and in the presence of analyte. The detection limits were calculated by use literature procedure (see details in Supporting Information). ${ }^{35}$

To investigate detection of nitroaromatic explosives in vapor phase the original device "Nitroscan» (see Fig. S8) has been used. "Nitroscan» was produced by "Promautomatika» Plant in collaboration with «UralProektAvtomatika» (Ekaterinburg, Russia) and "Security Intermolecular System» (Ekaterinburg, Russia). The instrument is based on registration of excited steady-state luminescence quenching. Sensors for this device were obtained by application of a dye solution on the cellulose matrix. Reduction of sensor's luminescence intensity takes place due to an interaction of explosive vapors containing in the air. The decrease rate of the luminescence intensity indicates at the concentration of vapors. To study luminescent properties of the sensor element, its luminescence spectra excited by photons with energies in the range $280 \div 425 \mathrm{~nm}$ were measured. The excitation photoluminescence spectra for luminescence bands of the sensor element were also measured. Excitation source was light emitting diode $(375 \mathrm{~nm})$ and luminescent signal receiver was a photodiode (430 $650 \mathrm{~nm}$ ) in the device designed. The device was operating under control of the program algorithm, which provides multiple operating modes (configuration, calibration, measurement etc.). The advantages of this device are autonomic power, a low weight and small sizes, as well as simplicity of operations for measurements. The calibration of the device "Nitroscan» was carried out with using of internal software. The fluorescence 
measurements (excited at $375 \mathrm{~nm}$ ) in solid phase were performed in device "Nitroscan" connected with a computer. More details about operation of the device «Nitroscan» are in reference. ${ }^{48}$

The sensor for detection of NACs in vapor phase has been designed as cartridge. The cartridge has two parts which are connected at the contour of the framework. The non-woven spunlace fabric has been used as a porous substrate (70\% viscose, 30\% polyester, Industrial Spunlace purchased from Afalina Co., Ltd., Russia) for the fabrication of sensor. A piece of non-woven spunlace (50 $\mathrm{mm}$ in diameter) was immerged in the fluorophore solution with a concentration $1.0 \times 10^{-3} \mathrm{M}$ for $5 \mathrm{~min}$. Then non-woven dry wipe or spunlace with immobilized fluorophore $\mathbf{7 a}\left(\mathbf{7 b}\right.$ or $\mathbf{7 c}$ ) was removed from the solution and dried at $70-80^{\circ} \mathrm{C}$ for $30 \mathrm{~min}$. To demonstrate its application as a fluorescence sensor for NACs detection, the obtained non-woven spunlace was placed in cartridge.

According to the general sanitary requirements for the working zone air of the Russian code for occupational safety, nitrobenzene (NB), 2,4-dinitrotoluene (DNT) and 2,4,6-trinitrotoluene (TNT) were found to have had a maximal allowable concentrations (MAC) of $3 \mathrm{mg} / \mathrm{m}^{3}[0.60 \mathrm{ppm}]$, of $1 \mathrm{mg} / \mathrm{m}^{3}$ [0.13 ppm], and $0.5 \mathrm{mg} / \mathrm{m}^{3}[0.05$ ppm], respectively. ${ }^{46}$

Nitrobenzene $5.8 \times 10^{-4} \mathrm{~g}$ was dissolved in $\mathrm{CH}_{3} \mathrm{CN} 10 \mathrm{~mL}$. To detect of vapor of the nitroaromatic explosive, the aliquots $100 \mu \mathrm{L}$ and $10 \mu \mathrm{L}$ of the obtained nitrobenzene solution were sprayed by a syringe in a hermetic glovebox $(0.8 \mathrm{~m} \times 0.6 \mathrm{~m} \times 0.4 \mathrm{~m})$ and kept in this box during $12 \mathrm{~h}$ at room temperature to achieve respectively a 0.01 $\left(0.03 \mathrm{mg} / \mathrm{m}^{3}\right.$ or $\left.6 \mathrm{ppb}\right)$ and $0.001\left(0.003 \mathrm{mg} / \mathrm{m}^{3}\right.$ or $\left.0.6 \mathrm{ppb}\right)$ of maximal allowable concentrations of nitrobenzene. DNT $1.9 \times 10^{-4} \mathrm{~g}$ was dissolved in $\mathrm{CH}_{3} \mathrm{CN} 10 \mathrm{~mL}$. To detect of vapor of the nitroaromatic explosive, the aliquot $100 \mu \mathrm{L}$ of the obtained DNT solution was sprayed by a syringe in a hermetic glove-box $(0.8 \mathrm{~m} \times 0.6 \mathrm{~m} \times 0.4 \mathrm{~m})$ and kept in this box during $12 \mathrm{~h}$ at room temperature to achieve a $0.1\left(0.1 \mathrm{mg} / \mathrm{m}^{3}\right.$ or $\left.1.3 \mathrm{ppb}\right)$ of maximal allowable concentrations of TNT.

Similarly, TNT $1.0 \times 10^{-4} \mathrm{~g}$ was dissolved in $\mathrm{CH}_{3} \mathrm{CN} 10 \mathrm{~mL}$. To detect of vapor of the nitroaromatic explosive, the aliquots $100 \mu \mathrm{L}$ and $10 \mu \mathrm{L}$ of the obtained TNT solution were sprayed by a syringe in a hermetic glove-box (0.8 $\mathrm{m} \times 0.6 \mathrm{~m} \times 0.4 \mathrm{~m})$ and kept in this box during $12 \mathrm{~h}$ at room temperature to achieve respectively a $0.1(0.05$ $\mathrm{mg} / \mathrm{m}^{3}$ or $\left.5 \mathrm{ppb}\right)$ and $0.01\left(0.005 \mathrm{mg} / \mathrm{m}^{3}\right.$ or $\left.0.5 \mathrm{ppb}\right)$ of maximal allowable concentrations of TNT.

To detect the vapor of interferents $(15 \mathrm{ml})$, such as ethanol, ethylene glycol, acetone, acetic acid, toluene, phenol, and 1,2-dichlorobenzene, their placed in a hermetic glove-box ( $0.8 \mathrm{~m} \times 0.6 \mathrm{~m} \times 0.4 \mathrm{~m})$. Interferent was kept in this box during 12 hours at room temperature until saturated vapor was reached.

A suitable crystal of $\mathbf{7 b}$ was selected and XRD analysis was performed on a Xcalibur diffractometer on standard procedure (MoK $\alpha$ graphite-monochromated irradiation, $\omega$-scanning with $1^{\circ}$ steps). The empirical absorption correction was applied. Using Olex $2^{49}$, the structure was solved with the SHELXS ${ }^{50}$ structure solution program and refined with the SHELXL ${ }^{50}$ refinement program using full-matrix least-squares on $\mathrm{F}^{2}$ method in anisotropic approximation for non-hydrogen atoms. Deposition number CCDC 1570333 for $7 \mathbf{b}$ contains the supplementary crystallographic data for this paper. These data can be obtained free of charge from the Cambridge Crystallographic Data Centre via www.ccdc.cam.ac.uk/data request/cif.

4,6-bis(5-Bromothiophen-2-yl)-5-(4-tert-butylphenyl)pyrimidine (5). NBS (890 mg, $5.0 \mathrm{mmol}$ ) was added to a solution of 5-(4-tert-butylphenyl)-4,6-di(thiophen-2-yl)pyrimidine (4) (377 mg, $1.0 \mathrm{mmol}$ ) in DMF (10 mL) at room temperature. Then the mixture was stirred for $24 \mathrm{~h}$ at room temperature. The reaction mixture was diluted with $\mathrm{H}_{2} \mathrm{O}$ and the precipitate formed was filtered, washed with $\mathrm{H}_{2} \mathrm{O}$, and air-dried. The residue was purified by flash column chromatography (hexane/ethyl acetate, 1:1). The product 5 was isolated as a yellow powder (492 mg, 92\%), mp 172-174 ${ }^{\circ} \mathrm{C} .{ }^{1} \mathrm{H}$ NMR (500 MHz, $\left.\mathrm{CDCl}_{3}\right) \delta 8.97(\mathrm{~s}, 1 \mathrm{H}), 7.65-7.54(\mathrm{~m}, 2 \mathrm{H}), 7.24-7.20$ $(\mathrm{m}, 2 \mathrm{H}), 6.77(\mathrm{~d}, \mathrm{~J} 4.2 \mathrm{~Hz}, 2 \mathrm{H}), 6.23(\mathrm{~d}, \mathrm{~J} 4.2 \mathrm{~Hz}, 2 \mathrm{H}), 1.44(\mathrm{~s}, 9 \mathrm{H}) ;{ }^{13} \mathrm{C} \mathrm{NMR}\left(126 \mathrm{MHz}, \mathrm{CDCl}_{3}\right) \delta 157.0,156.6,153.6$, 
144.1, 132.3, 131.4, 131.0, 129.1, 127.4, 125.1, 119.0, 35.0, 31.4. Calcd. for $\mathrm{C}_{22} \mathrm{H}_{18} \mathrm{Br}_{2} \mathrm{~N}_{2} \mathrm{~S}_{2}$ (534.34): C 49.45, $\mathrm{H}$ 3.40, N 5.24. Found C 49.55, H 3.24, N 5.37. HRMS (ESI): $\mathrm{m} / z$ calcd for $\mathrm{C}_{22} \mathrm{H}_{19} \mathrm{Br}_{2} \mathrm{~N}_{2} \mathrm{~S}_{2}$ : $534.9336[\mathrm{M}+\mathrm{H}]^{+}$; found: 534.9333.

General procedure for the synthesis of 4,6-bis[5-(heteroaryl)-thiophen-2-yl]-5-(4-tertbutylphenyl)pyrimidines (7a-c). A solution of $\mathrm{K}_{2} \mathrm{CO}_{3}(138 \mathrm{mg}, 1.0 \mathrm{mmol})$ in $\mathrm{H}_{2} \mathrm{O}(2 \mathrm{~mL})$ was added to a mixture of 4,6-bis(5-bromothiophen-2-yl)-5-(4-tert-butylphenyl)pyrimidine (5) (107 mg, $0.2 \mathrm{mmol}$ ) and pinacol ester 4(diphenylamino)phenylboronic (6a) acid [pinacol ester 9-ethyl-9H-carbazole-3-boronic (6b) acid or pyrene-1boronic acid (6c)] (0.44 mmol) and $\mathrm{Pd}\left(\mathrm{PPh}_{3}\right)_{4}(23 \mathrm{mg}, 10 \mathrm{~mol} \%)$ in 1,4-dioxane $(4 \mathrm{~mL})$. The resulting mixture was irradiated in a microwave apparatus at $160{ }^{\circ} \mathrm{C}(250 \mathrm{~W})$ for $30 \mathrm{~min}$. After that solvent was distilled off in vacuo, and the residue was purified by flash column chromatography (hexane/ethyl acetate, 1:2) to afford the desired cross-coupling products (7a, $7 \mathrm{~b}$ or $7 \mathrm{c})$.

4,4'-\{5,5'-[5-(4-Tert-butylphenyl)pyrimidine-4,6-diyl]bis(thiophene-5,2-diyl)\}bis( $\mathbf{N}, \mathbf{N}$-diphenylaniline)

(7a). Yield $142 \mathrm{mg}$ (82\%), yellow powder, mp 242-244 ${ }^{\circ} \mathrm{C} .{ }^{1} \mathrm{H}$ NMR $\left(500 \mathrm{MHz}, \mathrm{CDCl}_{3}\right) \delta 9.03(\mathrm{~s}, 1 \mathrm{H}), 7.69-7.65(\mathrm{~m}, 2 \mathrm{H})$, $7.63(\mathrm{~d}, J 8.1 \mathrm{~Hz}, 2 \mathrm{H}), 7.55(\mathrm{~m}, 1 \mathrm{H}), 7.47$ (dd, J 7.5, $2.5 \mathrm{~Hz}, 2 \mathrm{H}), 7.43$ (d, J $8.6 \mathrm{~Hz}, 4 \mathrm{H}), 7.32-7.24(\mathrm{~m}, 5 \mathrm{H}), 7.11(\mathrm{~d}$, J $7.8 \mathrm{~Hz}, 8 \mathrm{H}), 7.07-6.99(\mathrm{~m}, 8 \mathrm{H}), 6.93(\mathrm{~d}, J 4.1 \mathrm{~Hz}, 2 \mathrm{H}), 6.35$ (d, J $4.1 \mathrm{~Hz}, 2 \mathrm{H}), 1.45(\mathrm{~s}, 9 \mathrm{H}) ;{ }^{13} \mathrm{C} \mathrm{NMR}(126 \mathrm{MHz}$, $\left.\mathrm{CDCl}_{3}\right) \delta 157.5,156.6,148.6,149.0,147.3,140.9,133.5,132.3,132.1,132.1,131.93,131.90,129.4,128.5,128.4$, 127.4, 127.2, 126.6, 124.8, 123.4, 123.1, 123.0, 35.0, 31.5. Calcd. for $\mathrm{C}_{58} \mathrm{H}_{46} \mathrm{~N}_{4} \mathrm{~S}_{2}$ (863.17): C 80.71, H 5.37, N 6.49. Found C 80.94, H 5.24, N 6.57. HRMS (ESI): $m / z$ calcd for $\mathrm{C}_{58} \mathrm{H}_{47} \mathrm{~N}_{4} \mathrm{~S}_{2}: 863.3237[\mathrm{M}+\mathrm{H}]^{+}$; found: 863.3236 .

3,3'-\{5,5'-[5-(4-Tert-butylphenyl)pyrimidine-4,6-diyl]bis(thiophene-5,2-diyl)\}bis(9-ethyl-9H-carbazole) (7b). Yield $121 \mathrm{mg}(79 \%)$, dark yellow powder, mp $259-261^{\circ} \mathrm{C} .{ }^{1} \mathrm{H} \mathrm{NMR}\left(500 \mathrm{MHz}, \mathrm{CDCl}_{3}\right) \delta 9.10(\mathrm{~s}, 1 \mathrm{H}), 8.32$ (d, J 1.6 $\mathrm{Hz}, 2 \mathrm{H}), 8.07(\mathrm{~d}, J 7.7 \mathrm{~Hz}, 2 \mathrm{H}), 7.72(\mathrm{~d}, J 1.7 \mathrm{~Hz}, 1 \mathrm{H}), 7.71-7.66(\mathrm{~m}, 3 \mathrm{H}), 7.52-7.45(\mathrm{~m}, 2 \mathrm{H}), 7.40(\mathrm{~d}, J 8.1 \mathrm{~Hz}, 2 \mathrm{H})$, $7.37(\mathrm{~d}, J 8.3 \mathrm{~Hz}, 4 \mathrm{H}), 7.25(\mathrm{~m}, 2 \mathrm{H}), 7.09(\mathrm{~d}, J 4.1 \mathrm{~Hz}, 2 \mathrm{H}), 6.45(\mathrm{~d}, J 4.1 \mathrm{~Hz}, 2 \mathrm{H}), 4.36(\mathrm{q}, J \mathrm{~J} .2 \mathrm{~Hz}, 4 \mathrm{H}), 1.52(\mathrm{~s}, 9 \mathrm{H})$, $1.44(\mathrm{t}, J 7.2 \mathrm{~Hz}, 6 \mathrm{H}) ;{ }^{13} \mathrm{C} \mathrm{NMR}\left(126 \mathrm{MHz}, \mathrm{CDCl}_{3}\right) \delta 157.6,156.7,153.0,150.4,140.6,140.5,139.9,133.7,132.4$, 129.6, 127.3, 126.1, 125.2, 125.0, 124.0, 123.4, 122.89, 122.88, 120.5, 119.3, 118.0, 108.8, 108.7, 37.7, 35.0, 31.6, 13.8. Calcd. for $\mathrm{C}_{50} \mathrm{H}_{42} \mathrm{~N}_{4} \mathrm{~S}_{2}$ (763.05): C 78.71, $\mathrm{H}$ 5.55, N 7.43. Found C 78.84, H 5.44, N 7.57. HRMS (ESI): $\mathrm{m} / \mathrm{z}$ calcd for $\mathrm{C}_{50} \mathrm{H}_{43} \mathrm{~N}_{4} \mathrm{~S}_{2}: 763.2924[\mathrm{M}+\mathrm{H}]^{+}$; found: 763.2910 .

5-(4-Tert-butylphenyl)-4,6-bis[5-(pyren-1-yl)thiophen-2-yl]pyrimidine (7c). Yield $92 \mathrm{mg}$ (59\%), yellow powder, $\mathrm{mp} 304-306{ }^{\circ} \mathrm{C} .{ }^{1} \mathrm{H}$ NMR $\left(500 \mathrm{MHz}, \mathrm{CDCl}_{3}\right) \delta 9.15(\mathrm{~s}, 1 \mathrm{H}), 8.51(\mathrm{~d}, J 9.3 \mathrm{~Hz}, 2 \mathrm{H}), 8.24-8.16(\mathrm{~m}, 6 \mathrm{H}), 8.13-8.06(\mathrm{~m}$, $8 \mathrm{H}), 8.06-8.00(\mathrm{~m}, 2 \mathrm{H}), 7.74(\mathrm{~d}, J 8.2 \mathrm{~Hz}, 2 \mathrm{H}), 7.48(\mathrm{~d}, J 8.2 \mathrm{~Hz}, 2 \mathrm{H}), 7.15(\mathrm{~d}, J 3.9 \mathrm{~Hz}, 2 \mathrm{H}), 6.66(\mathrm{~d}, J 3.9 \mathrm{~Hz}, 2 \mathrm{H})$, $1.47(\mathrm{~s}, 9 \mathrm{H})$. The ${ }^{13} \mathrm{C}$ NMR spectra of compound 7c could not be obtained due to the poor solubility of this compound in deuteriated solvents. Calcd. for $\mathrm{C}_{54} \mathrm{H}_{36} \mathrm{~N}_{4} \mathrm{~S}_{2}$ (777.03): C 83.47, $\mathrm{H} 4.67, \mathrm{~N} 3.61$. Found $\mathrm{C} \mathrm{83.28,} \mathrm{H}$ 4.84, N 3.49. HRMS (ESI): $m / z$ calcd for $\mathrm{C}_{54} \mathrm{H}_{37} \mathrm{~N}_{2} \mathrm{~S}_{2}$ : $777.2391[\mathrm{M}+\mathrm{H}]^{+}$; found: 777.2393.

\section{Acknowledgements}

The research was financially supported by the Russian Science Foundation (Project No. 16-13-10435).

\section{Supplementary Material}

Additional supporting information can be found in the online version of this article at the publisher's website. 


\section{References}

1. Germain, M. E.; Knapp, M. J. Chem. Soc. Rev. 2009, 38, 2543-2555. https://dx.doi.org/10.1039/B809631G

2. Krausa, M.; Reznev, A.A. Vapor and trace detection of explosives for antiterrorism purposes. Boston: Kluwer Academic Publisher; 2004.

3. Salinas, Y.; Martínez-Máñez, R.; Marcos, M. D.; Sancenón, F.; Costero, A. M.; Parra, M.; Gil, S. Chem. Soc. Rev. 2012, 41, 1261-1296.

https://dx.doi.org/0.1039/c1cs15173h

4. Sunahara, G. I.; Lotufo, G.; Kuperman, R. G.; Hawari, J. Ecotoxicology of explosives. Boca Raton, London, New York: CRC Press Taylor \& Francis; 2009.

5. Hakonen, A.; Andersson, P. O.; Schmidt, M. S.; Rindzevicius, T.; Käll, M. Anal. Chim. Acta 2015, 893, 1-13. https://dx.doi.org/10.1016/j.aca.2015.04.010

6. Håkansson, K.; Coorey, R. V.; Zubarev, R. A.; Talrose, V. L.; Håkansson, P. J. Mass. Spectrom. 2000, 35, 337346.

https://dx.doi.org/10.1002/(SICI)1096-9888(200003)35:3<337::AID-JMS940>3.0.CO;2-7

7. Mu, R. P.; Shi, H. L.; Yuan, Y.; Karnjanapiboonwong, A.; Burken, J. G.; Ma, Y. F. Anal. Chem. 2012, 84, 34273432.

https://dx.doi.org/10.1021/ac300306p

8. Berg, M.; Bolotin, J.; Hofstetter, T. B. Anal. Chem. 2007, 79, 2386-2393.

https://dx.doi.org/10.1021/ac0622577

9. Anferov, V. P.; Mozjoukhine, G. V.; Fisher R. Rev. Sci. Instrum. 2000, 71, 1656-1659.

https://dx.doi.org/10.1063/1.1150514

10. O'Flynn, D.; Reid, C. B.; Christodoulou, C.; Wilson, M. D.; Veale, M. C.; Seller, P.; Hills, D.; Desai, H.; Wong, B.; Spelle, R. J. Instrum. 2013, 8, P03007.

11. Wallis, E.; Griffin, T. M.; Popkie, J. N.; Eagan, M. A.; McAtee, R. F.; Vrazel, D.; McKinly, J. Proc. SPIE-Int. Soc. Opt. Eng. 2005, 5795, 54-64.

12. Tabrizchi, M.; Ilbeigi, V. J. Hazard. Mater. 2010, 176, 692-696.

https://dx.doi.org/10.1016/j.jhazmat.2009.11.087

13. Brown, K. E.; Greenfield, M. T.; McGrane, S. D.; Moore, D. S. Anal. Bioanal. Chem. 2016, 408, 35-47. https://dx.doi.org/10.1007/s00216-015-9040-4

14. Brown, K. E.; Greenfield, M. T.; McGrane, S. D.; Moore, D. S. Anal. Bioanal. Chem. 2016, 408, 49-65. https://dx.doi.org/10.1007/s00216-015-9043-1

15. Giannoukos, S.; Brkić, B.; Taylor, S.; Marshall, T.; Verbeck, G. F. Chem. Rev. 2016, 116, 8146-8172. https://dx.doi.org/10.1021/acs.chemrev.6b00065

16. Website of FLIR Systems Inc.: http://www.flir.com/GB/

17. Website of the portable detector of nitro-explosives «Nitroscan»: http://nitroscan.pro.

18. Guan, W.; Zhou, W.; Lu, J.; Lu, C. Chem. Soc. Rev. 2015, 44, 6981-7009.

https://dx.doi.org/10.1039/C5CS00246J

19. Shanmugaraju, S.; Mukherjee, P. S. Chem. Commun. 2015, 51, 16014-16032. https://dx.doi.org/10.1039/C5CC07513K

20. Acharyya, K.; Mukherjee, P. S. Chem. Commun. 2014, 50, 15788-15791. https://dx.doi.org/10.1039/C4CC06225F

21. Gu, C.; Huang, N.; Wu, Y.; Xu, H.; Jiang, D. Angew. Chem. Int. Ed. 2015, 54, 11540- 11544. 
https://dx.doi.org/10.1002/anie.201504786

22. Zhang, Y.; Pan, J.; Zhang, C.; Wang, H.; Zhang, G.; Kong, L.; Tian, Y.; Yang, J. Dyes Pigments 2015, 123, 257266.

https://dx.doi.org/10.1016/j.dyepig.2015.08.013

23. Deshmukh, S. C.; Rana, S.; Shinde, S. V.; Dhara, B.; Ballav, N.; Talukdar, P. ACS Omega 2016, 1, 371-377. https://dx.doi.org/10.1021/acsomega.6b00136

24. Bhaskar, A.; Ramakrishna, G.; Lu, Z.; Twieg, R.; Hales, J. M.; Hagan, D. J.; Van Stryland, E.; Goodson, T. J. Am. Chem. Soc. 2006, 128, 11840-11849.

https://dx.doi.org/10.1021/ja060630m

25. Bordeau, G.; Lartia, R.; Metge, G.; Fiorini-Debuisschert, C.; Charra, F.; Teulade-Fichou, M. P. J. Am. Chem. Soc. 2008, 130, 16836-16837.

https://dx.doi.org/10.1021/ja8055112

26. Sonu, S.; Tiwari, A. K.; Sarmah, A.; Roy, R. K.; Saha, S. K. Dyes Pigments 2014, 102, 114-125. https://dx.doi.org/10.1016/i.dyepig.2013.10.040

27. Achelle, S.; Nouira, I.; Pfaffinger, B.; Ramondenc, Y.; Plé, N.; Rodríguez-López, J. J. Org. Chem. 2009, 74, 3711-3717.

https://dx.doi.org/10.1021/jo900107u

28. Kato, S.; Yamada, Y.; Hiyoshi, H.; Umezu, K.; Nakamura, Y. J. Org. Chem. 2015, 80, 9076-9090. https://dx.doi.org/10.1021/acs.joc.5b01409

29. Achelle, S.; Barsella, A.; Caroa, B.; Robin-le Guen, F. RSC Adv. 2015, 5, 39218-39227. https://dx.doi.org/10.1039/C5RA05736A

30. Tang, R.; Wang, X.; Zhang, W.; Zhuang, X.; Bi, S.; Zhang, W.; Zhang, F. J. Mater. Chem. C 2016, 4, 7640. https://dx.doi.org/10.1039/C6TC02591A

31. Achelle, S.; Bodiou, L.; Charrier, J.; Robin-le Guen, F. C. R. Chim. 2016, 19, 279-285. https://dx.doi.org/10.1016/j.crci.2015.07.014

32. Cvejn, D.; Achelle, S.; Pytela, O.; Malval, J. P.; Spangenberg, A.; Cabon, N.; Bureš, F.; Robin-le Guen, F. Dyes Pigments 2016, 124, 101-109.

https://dx.doi.org/10.1016/i.dyepig.2015.09.012

33. Peng, Y. ; Zhang, A.-J. ; Dong, M. ; Wang, Y.-W. Chem. Commun. 2011, 47, 4505-4507. https://dx.doi.org/10.1039/c1cc10400d

34. Santra, D. C.; Bera, M. K.; Sukul, P. K.; Malik, S. Chem. Eur. J. 2016, 22, 2012-2019. https://dx.doi.org/10.1002/chem.201504126

35. Verbitskiy, E. V.; Baranova, A. A.; Lugovik, K. I.; Shafikov, M. Z.; Khokhlov, K. O.; Cheprakova, E. M.; Rusinov, G. L.; Chupakhin, O. N.; Charushin, V. N. Anal. Bioanal. Chem. 2016, 408, 4093-4101. https://dx.doi.org/10.1007/s00216-016-9501-4

36. Verbitskiy, E. V.; Baranova, A. A.; Lugovik, K. I.; Khokhlov, K. O.; Cheprakova, E. M.; Rusinov, G. L.; Chupakhin, O. N.; Charushin, V. N. ARKIVOC 2016, iii, 360-373.

https://dx.doi.org/10.3998/ark.5550190.p009.470

37. Verbitskiy, E. V.; Gorbunov, E. B.; Baranova, A. A.; Lugovik, K. I.; Khokhlov, K. O.; Cheprakova, E. M.; Kim, G. A.; Rusinov, G. L.; Chupakhin, O. N.; Charushin, V. N. Tetrahedron 2016, 72, 4954-4961. https://dx.doi.org/10.1016/j.tet.2016.06.071

38. Verbitskiy, E. V.; Cheprakova, E. M.; Baranova, A. A.; Khokhlov, K. O.; Lugovik, K. I.; Rusinov, G. L.; Chupakhin, O. N.; Charushin, V. N. Chem. Heterocycl. Compd. 2016, 52, 904-909. https://dx.doi.org/10.1007/s10593-017-1984-1 
39. Baranova, A. A.; Khokhlov, K. O.; Chuvashov, R. D.; Verbitskiy, E. V.; Cheprakova, E. M.; Rusinov, G. L.; Charushin, V. N. J. Phys. Conf. Ser. 2017, 830, 012159.

https://dx.doi.org/10.1088/1742-6596/755/1/011001

40. Verbitskiy, E. V.; Baranova, A. A.; Lugovik, K. I.; Khokhlov, K. O.; Cheprakova, E. M.; Shafikov, M. Z.; Rusinov, G. L.; Chupakhin, O. N.; Charushin, V. N. Dyes Pigments 2017, 137, 360-371.

https://dx.doi.org/10.1016/i.dyepig.2016.10.039

41. Achelle, S.; Baudequin, C. In: Attanasi OA, Spinelli D, editors. Targets in heterocyclic systems, vol. $17 ; 2013$. p. 1-34.

42. Chupakhin, O. N.; Charushin, V. N. Tetrahedron Lett. 2016, 57, 2665-2672. https://dx.doi.org/10.1016/i.tetlet.2016.04.084

43. Verbitskiy, E. V.; Cheprakova, E. M.; Makarova, N. I.; Dorogan, I. V.; Metelitsa, A. V.; Minkin, V. I.; Slepukhin, P. A.; Svalova, T. S.; Ivanova, A. V.; Kozitsina, A. N.; Rusinov, G. L.; Chupakhin, O. N.; Charushin, V. N. Eur. J. Org. Chem. 2016, 7, 1420-1428.

https://dx.doi.org/10.1002/ejoc.201501450

44. Qu, Y.-J.; Li, J. Inorg. Chem. Commun. 2017, 76, 77. https://dx.doi.org/10.1016/j.inoche.2017.01.015

45. Tian, X.; Peng, H.; Li, Y.; Yang, C.; Zhou, Z.; Wang, Y. Sensors and Actuators B 2017, 243, 1002-1009. https://dx.doi.org/10.1016/j.snb.2016.12.079

46. GOST 12.1.005-88. "Occupational Safety Standard System. General Sanitary Requirements for Working Zone Air" [in Russian], Moskovskii Pechatnik, Moscow (1988).

47. Brouwer, A. M. Pure Appl. Chem. 2011, 83, 2213-2228. https://dx.doi.org/10.1351/PAC-REP-10-09-31

48. Baranova, A. A.; Khokhlov, K. O. J. Phys. Conf. Ser. 2014, 552, 012034. https://dx.doi.org/10.1088/1742-6596/552/1/012034

49. Dolomanov, O. V.; Bourhis, L. J.; Gildea, R. J.; Howard, J. A. K.; Puschmann, H. J. Appl. Crystallogr. 2009, 42, 339-341. https://dx.doi.org/10.1107/S0021889808042726

50. Sheldrick, G. M. Acta Crystallogr., Sect. A 2008, 64, 112-122. https://dx.doi.org/10.1107/S010876730704393 